\title{
Efektivitas Berkumur Ekstrak Kulit Apel Manalagi (Malus sylvestris Mill.) 12,5\% terhadap Penurunan Indeks Plak
}

\author{
Raphael $\mathrm{A}^{1}$, Soegiharto $\mathrm{S}^{1}$, Evacuasiany $\mathrm{E}^{1}$ \\ 1.Fakultas Kedokteran Gigi, Universitas Kristen Maranatha, Bandung, 40164, Indonesia \\ Email: alexanderraphael121@yahoo.com
}

\begin{abstract}
Abstrak
Penyakit periodontal merupakan salah satu penyakit yang umum ditemukan diseluruh dunia. Berdasarkan Hasil Riset Kesehatan Dasar (RISKESDAS) persentase penduduk Indonesia yang memiliki masalah gigi mulut pada tahun 2007 dan 2013 mengalami peningkatan dari $23,2 \%$ menjadi $25,9 \%$. Penyebab utama adalah plak. Bakteri yang dominan pada plak merupakan golongan Streptococcus seperti Streptococcus mutans, Staphylococcus aureus, Neiseria sp, dan masih banyak lagi. Pembentukan plak dapat dicegah dengan berkumur ekstrak apel manalagi (Malus sylvestris Mill.) dengan konsentrasi 12,5\%. Tujuan pada penelitian ini untuk mengetahui efek berkumur ekstrak apel manalagi (Malus sylvestris Mill.) dalam menurunkan indeks plak gigi.

Racangan penelitian ini merupakan penelitian eksperimental semu dengan desain pre-test dan post-test. Subjek penelitian sebanyak 32 orang yang dibagi menjadi 2 kelompok secara acak $(\mathrm{n}=16)$. Kelompok pertama berkumur dengan ekstrak kulit apel manalagi (Malus sylvestris Mill.) dan kelompok kedua sebagai kontrol berkumur dengan air mineral. Data yang diukur adalah indeks plak gigi dengan metode O'Leary. Analisis data persentase indeks plak gigi menggunakan paired T-test dan independent $T$ test dengan $\alpha=0,05$.

Hasil penelitian menunjukan rata - rata indeks plak gigi sebelum dan sesudah berkumur ekstrak kulit apel manalagi (Malus sylvestris Mill.) sebersar 29,02\% dan $16,18 \%$. Hasil analisis data didapatkan nilai $\mathrm{p}<0,05$ berarti terdapat perbedaan yang signifikan antara kelompok yang berkumur ekstrak kulit apel manalagi (Malus sylvestris Mill.) 12,5\% dengan air mineral.

Simpulan dari penelitian ini adalah berkumur dengan ekstrak kulit apel manalagi (Malus sylvestris Mill.) 12,5\% dapat menurunkan indeks plak gigi.
\end{abstract}

Effectivity of Gargling Manalagi Apple Peel Extract (Malus sylvestris Mill.) 12,5\% to Decrease Dental Plaque Index

\section{Abstract}

Periodontal disease is one of the most common diseases worldwide. Based on Riset Kesehatan Dasar (RISKESDAS) the percentage of Indonesian population with oral dental problems in 2007 and 2013 increased from 23.2\% to 25.9\%. The primary cause of periodontal disease is plaque. The dominant bacteria in plaque are Streptococcus groups such as Streptococcus mutans, Staphylococcus aureus, Neiseria $s p$, and many more. The formation of dental plaque can be prevented by rinsing 
manalagi apple's peel extract (Malus sylvestris Mill.) with 12,5\% concentration. The purpose of this study was to investigate the effect of gargling manalagi apple's peel extract (Malus sylvestris Mill.) in decreasing index of dental plaque.

This study design was a quasi experimental research with pre-test and post-test design. Research subjects were 32 people divided into 2 groups at randoml $(n=16)$. The first group treated by rinsing with manalagi apple's peel extract (Malus sylvestris Mill.) and the second group was treated by rinsing mineral water as control. Measure data was plaque index using O'Leary methods. Data analysis of percentage of dental plaque index using paired T-test and independent T test with $\alpha$ $=0,05$.

The results of the study showed the average of dental plaque index before and after rinse manalagi apple's peel extract (Malus sylvestris Mill.) was 29.02\% and $16.18 \%$. The result of data analysis showed the value of $p<0,05$, it means there is a significant difference in the grup rinsed with manalagi apple's peel extract (Malus sylvestris Mill.) 12,5\% and mineral water. The conclusions of this study is rinse with manalagi apple's peel extract (Malus sylvestris Mill.) 12.5\% can decrease the dental plaque index

Keywords: dental plaque; dental plaque index; manalagi apple's peel extract (Malus sylvestris Mill.).

\section{Pendahuluan}

Penyakit periodontal merupakan salah satu penyakit yang ditemukan diseluruh dunia, termasuk di Indonesia. Persentase penduduk Indonesia menurut Hasil Riset Kesehatan Dasar (RISKESDAS) masalah gigi dan mulut dan penyakit periodontal terjadi peningkatan sebesar hampir 3\% dari $23,2 \%$ menjadi $25,9 \%$. Etiologi penyakit periodontal diawali dengan penumpukan plak.

Penumpukan plak pada permukaan gigi merupakan penyebab utama penyakit periodontal. Plak gigi dapat didefinisikan sebagai deposit lunak yang membentuk lapisan biofilm yang menempel pada permukaan gigi atau permukaan keras lain dalam rongga mulut. Tingkat pembentukan plak dan lokasi plak bervariasi antar individu dan dapat dipengaruhi oleh pola makan, usia, faktor saliva, kebersihan mulut, kesejajaran gigi, penyakit sistemik, dan host factor.

Plak gigi merupakan faktor utama dalam proses terjadinya karies pada gigi dan jaringan periodontal. Pengendalian plak merupakan hal penting untuk mencegah terjadi karies dan penyakit periodontal. Pengendalian plak dapat dilakukan secara mekanik dan kimiawi. Kontrol plak secara mekanik yaitu dengan menggunakan sikat gigi dan benang gigi, sedangkan kontrol plak secara kimiawi dapat dilakukan dengan menggunakan obat kumur.

Beberapa substansi kimia dalam obat kumur memiliki sifat antiseptik atau antibakteri yang berguna untuk menghambat pembentukan plak. Obat kumur digunakan untuk menjangkau daerah gigi yang sulit dijangkau dengan sikat gigi seperti daerah interproksimal, mengurangi bakteri rongga mulut, membuang pelikel makanan, mengurangi halitosis akut sementara, dan memberikan rasa nyaman pada rongga mulut. Penggunaan obat tradisional menjadi alternatif pengobatan disamping 
pengobatan modern.

Apel merupakan salah satu buah yang populer di Indonesia. Tidak hanya bagian daging pada buah apel yang bermanfaat, kulit buah apel juga memiliki kandungan gizi yang tinggi. Kulit buah apel bermanfaat sebagai antibakteri, antioksidan, antifungi dan antiproliferatif, bahkan senyawa polifenol pada kulit buah apel nilainya lebih tinggi dibandingkan danging buah apel.

Indonesia merupakan negara yang kaya akan tanaman obat. Manfaat penggunaan obat tradisional secara luas telah dirasakan oleh masyarakat. Hal ini juga tercermin dengan semakin meningkatnya penggunaan obat tradisional.

Kulit buah apel manalagi (Malus sylvestris Mill.) memiliki kandungan zat aktif yang terdiri dari polifenol, fitokimia turunan polifenol (terdiri dari katekin, kuersetin, dan asam klorogenik), dan flavonoid. Kandungan zat aktif ini dapat dimanfaatkan sebagai antibakteri maupun antifungi, dimana dengan aktivitas dari kandungan ini dapat merusak membran sel dari mikroorganisme. Polyfenol akan menghambat glukosiltransferase, yaitu enzim yang diproduksi oleh bakteri Streptococcus dan mencegah pembentukan bahan matriks yang digunakan plak untuk melekat pada permukaan gigi. Polyfenol bekerja pada enzim alpha amylase untuk menghambat pemecahan karbohidrat, sehingga tidak terjadi pembentukan karbohidrat yang mudah difermentasikan (maltose). Kandungan yang terdapat pada kulit buah apel manalagi (Malus sylvestris Mill.) ini dapat menghambat pertumbuhan dan perkembangan bakteri.

\section{Metode Penelitian}

\section{Bahan dan Alat}

Bahan yang digunakan antara lain air mineral, ekstrak kulit apel manalagi (Malus sylvestris Mill.) 12,5\%, pasta gigi, makanan manis (coklat), disclosing solution, alkohol $70 \%$.

Alat yang digunakan antara lain handscoon, masker, slabber, alat dasar (kaca mulut, sonde, pinset, dan eskavator), baki steril, timer, sikat gigi, sendok takar, gelas kumur.

Variabel Penelitian

Variabel bebas pada penelitian ini berupa ekstrak kulit apel manalagi (Malus sylvestris

Mill.) $12,5 \%$ dan air mineral.

\section{Subjek Penelitian}

1. Kelompok I: berkumur dengan ekstrak kulit apel manalagi (Malus sylvestris Mill.) $12,5 \%$

2. Kelompok II: berkumur dengan air mineral 


\section{Persiapan Bahan Uji}

Buah apel manalagi sebanyak $12 \mathrm{~kg}$ dikupas dan diambil bagian kulitnya kemudian dikering anginkan selama kira - kira 7 hari sehingga didapatkan kulit apel yang kering seberat 400 gram. Kulit apel manalagi kemudian dihaluskan menggunakan blender hingga berbentuk potongan halus kemudian dimasukan ke maserator, dicampur dengan larutan ethanol 95\%, diaduk, kemudian ditutup, diamkan selama 8 jam. Kemudian lakukan penyaringan atau perkolasi dengan menggunakan perkolator. Berikutnya proses evaporasi dapat dilakukan menggunakan alat evaporator. Suhu air pada waterbath dipanaskan sampai didapatkan suhu stabil pada $50^{\circ} \mathrm{C}$. Masukan esktrak kulit apel manalagi yang telah dilakukan penyaringan ke dalam labu evaporasi dan tunggu 1 sampai 2 jam. Hasil evaporasi kemudian disimpan pada wadah, dan diletakan pada tempat terbuka sampai didapatkan tekstur yang kental. Setelahnya dapat disimpan pada lemari pendingan agar lebih tahan lama.

\section{Persiapan Subjek Penelitian}

Peneliti memberikan penjelasan kepada subjek mengenai alur penelitian dan meminta untuk menandatangani informed consent. Subjek diedukasi mengenai OHI (Oral Hygiene Intruction) mengenai cara menyikat gigi yang benar, pemilihan pasta gigi berflouride, dan pemeliharaan rongga mulut yang sehat. Subjek diintruksikan untuk menyikat gigi sesuai dengan intruksi yang telah dijelaskan menggunakan metode bass dan horizontal. Peneliti melakukan pemeriksaan pada rongga mulut subjek untuk menentukan apakah subjek masuk ke dalam kriteria inklusi.

\section{Pelaksanaan Penelitian}

Setelah subjek penelitian selesai menyikat gigi, subjek diberikan makanan manis (coklat). Subjek tidak diperbolehkan untuk makan - makanan lain selain makan yang telah disiapkan selama tiga jam. Subjek hanya diperbolehkan minum air mineral menggunakan sedotan. Subjek diberikan dislosing solution dan diperiksa indeks plaknya. Berikan perlakuan pada kelompok subjek yang berkumur dengan larutan ekstrak kulit apel manalagi 12,5\% sebanyak 2 kali berdurasi 30 detik sebanyak $20 \mathrm{ml}$. Berikan perlakuan pada kelompok subjek yang berkumur dengan air mineral sebanyak 2 kali berdurasi 30 detik sebanyak 20 ml. Lakukan perhitungan indeks plak kembali.

\section{Pemeriksaan Indeks Plak}

Metode yang digunakan adalah O'Leary dengan cara memeriksa plak pada seluruh permukaan gigi dengan bantuan kaca mulut. Terdapat empat permukaan gigi yang diperiksa yaitu: labial atau bukal, lingual atau palatal, mesial, dan distal. Pemeriksaan dilakukan dengan memberikan dislosing solution yang diteteskan dibawah lidah dan diratakan ke seluruh permukaan gigi menggunakan lidah. Lakukan pemeriksaan plak gigi dan hitung presentase plak gigi pada setiap subjek penelitian. Permukaan gigi yang berwarna merah diberi tanda $(+)$, sedangkan yang tidak terlihat warna merah diberikan tanda (-). Jumlahkan seluruh permukaan gigi yang telah ditandai (+) dan seluruh jumlah permukaan gigi yang diperiksa. Lakukan perhitungan persentasi plak gigi pada setiap subjek penelitian dengan menggunakan rumus: 
$\frac{\text { Jumlah plak gigi }}{\text { Jumlah permukaan gigi }} \times 100 \%$

Setelah dilakukan perhitungan maka didapatkan indeks plak.

\section{Analisa Statistik}

Analisis data penurunan indeks palk dihitung menggunakan software SPSS di komputer dengan metode eksperimental semu dengan desain pre test dan post test dengan kemaknaan ditentukan berdasar nilai $\mathrm{p}<0,05$. Normalitas data diperiksa menggunakan uji $\mathrm{T}$ - test berpasangan jika data berdistribusi normal dan uji Wilcoxon jika data tidak berdistribusi normal.

\section{Hasil}

Analisis data mengenai analisis deskriptif berupa rerata, standar deviasi, nilai maksimum dan nilai minimum serta analisis uji perbandingan untuk melihat pengaruh ekstrak kulit apel (Malus sylvestris Mill.) dan air minreal sebagai pembanding (kontrol). Percobaan ini dilakukan dua kali yaitu menghitung indeks plak setelah makan dan setelah berkumur dengan ekstrak kulit apel manalagi (Malus sylvestris Mill.).

Analisis Deskriptif Kelompok Berkumur Ekstrak Kulit Apel Manalagi

Berdasarkan tabel di bawah ini, dari 16 sampel yang di uji, sebelum berkumur dengan ekstrak kulit apel (Malus sylvestris Mill.) indeks plak minimumnya 13,39\% maksimumnya 48,21\%, rata-ratanya $29,02 \%$, dengan standar deviasi sebesar 9,42\%. Sementara setelah berkumur dengan ekstrak kulit apel (Malus sylvestris Mill.) indeks plak minimumnya berubah menjadi $6,25 \%$, maksimumnya $31,25 \%$, rata-ratanya $16,18 \%$, dengan standar deviasi sebesar $5,84 \%$.

Tabel 1. Persentase Indeks Plak Sebelum dan Sesudah Berkumur dengan Ekstrak Kulit Apel Manalagi (Malus sylvestris Mill.).

\begin{tabular}{llllll}
\hline & \multirow{N}{*}{} & Minimum & Maximum & Mean & $\begin{array}{l}\text { Std. } \\
\text { Deviation }\end{array}$ \\
\hline Pretest & 16 & 13,39 & 48,21 & 29,02 & 9,42 \\
\hline Posttest & 16 & 6,25 & 31,25 & 16,18 & 5,84 \\
\hline
\end{tabular}

Uji Normalitas Kelompok Berkumur Ekstrak Kulit Apel Manalagi

Berdasarkan tabel di bawah ini, pada data sebelum diberi perlakuan (pre test) dan setelah siberi perlakuan (post test) nilai p-value $>0,05$ artinya baik pada sebelum dan setelah diberi perlakuan data menunjukkan distribusi yang normal. Karena data 
sebelum dan sesudah diberi perlakuan ekstrak kulit apel manalagi (Malus sylvestris Mill.) memililiki distribusi data yang normal maka uji perbandingan menggunakan uji paired t-test.

Tabel 2. Uji Normalitas Data Ekstrak Kulit Apel Manalagi

\begin{tabular}{cccc}
\hline \multirow{2}{*}{ Kelompok } & \multicolumn{3}{c}{ Shapiro-Wilk } \\
\cline { 2 - 4 } & Statistic & $\boldsymbol{d f}$ & $\boldsymbol{p}$-value \\
\hline Pretest & 0,967 & 16 & 0,787 \\
\hline Posttest & 0,926 & 16 & 0,208 \\
\hline
\end{tabular}

Analisis Uji Perbandingan Indeks Plak Gigi Kelompok Berkumur Ekstrak Kulit Apel Manalagi

Berdasarkan tabel di bawah ini, pada uji perbandingan sebelum dan sesudah berkumur dengan ekstrak kulit apel manalagi (Malus sylvestris Mill.) menunjukkan nilai $p$-value sebesar 0,000 . Karena nilai $p$-value $(0,000)<0,05$ artinya terdapat perbedaan antara sebelum dengan sesudah berkumur dengan ekstrak kulit apel manalagi (Malus sylvestris Mill.). Oleh karena itu terdapat pengaruh berkumur dengan ekstrak kulit apel manalagi (Malus sylvestris Mill.) terhadap penurunan indeks plak gigi.

Tabel 3. Uji Perbandingan Indeks Plak Sebelum dan Sesudah Berkumur dengan Ekstrak Kulit Apel Manalagi (Malus sylvestris Mill.)

\begin{tabular}{llll}
\hline Kelompok & Mean $(\%)$ & $p$-value & Kesimpulan \\
\hline Pretest & 29,02 & $0,000^{*}$ & terdapat \\
Posttest & 16,18 & & perbedaan \\
\hline
\end{tabular}

\section{*)Paired t-test}

\section{Analisis Deskriptif Berkumur Air Mineral}

Berdasarkan tabel di bawah ini, dari 16 sampel yang di uji, sebelum berkumur dengan air mineral indeks plak minimumnya 10,58\% dan maksimumnya 40,18\%, rata-ratanya $24,38 \%$, dengan standar deviasi sebesar $8,69 \%$. Sementara setelah berkumur dengan air mineral indeks plak minimumnya berubah menjadi $6,70 \%$, maksimumnya $48,21 \%$, rata-ratanya $24,16 \%$, dengan standar deviasi sebesar $10,22 \%$. 
Tabel 4. Persentase Indeks Plak Sebelum dan Sesudah Berkumur dengan Air Mineral.

\begin{tabular}{llllll}
\hline & \multirow{N}{*}{} & Minimum & Maximum & Mean & $\begin{array}{l}\text { Std. } \\
\text { Deviation }\end{array}$ \\
\hline Pretest & 16 & 10,58 & 40,18 & 24,38 & 8,69 \\
\hline Posttest & 16 & 6,70 & 48,21 & 24,16 & 10,22 \\
\hline
\end{tabular}

Uji Normalitas Berkumur Air Mineral

Berdasarkan tabel di bawah, pada data sebelum diberi perlakuan (pretest) dan setelah siberi perlakuan (posttest) nilai $p$-value nya lebih besar dari 0,05 artinya baik pada sebelum dan setelah diberi perlakuan data menunjukkan distribusi yang normal. Karena data sebelum dan sesudah diberi perlakuan air mineral memililiki distribusi data yang normal maka uji perbandingan menggunakan uji paired t-test.

Tabel 5. Uji Normalitas Data Air Mineral

\begin{tabular}{lccc}
\hline Kelompok & & \multicolumn{2}{c}{ Shapiro-Wilk } \\
\hline Statistic & & $\boldsymbol{d f}$ & $\boldsymbol{p}$-value \\
\hline Pretest & 0,964 & 16 & 0,738 \\
\hline Posttest & 0,916 & 16 & 0,148 \\
\hline
\end{tabular}

Analisis Uji Perbandingan Indeks Plak Gigi Berkumur Air Mineral

Berdasarkan tabel di bawah, pada uji perbandingan sebelum dan sesudah berkumur dengan air mineral menunjukkan nilai $p$-value sebesar 0,870 . Karena nilai $p$-value $(0,000)>0,05$ artinya tidak terdapat perbedaan antara sebelum dengan sesudah diberi air mineral. Oleh karena itu tidak terdapat pengaruh signifikan pemberian air mineral terhadap perubahan indeks plak.

Tabel 6. Uji Perbandingan Indeks Plak Gigi Sebelum dan Sesudah Berkumur dengan Air Mineral

\begin{tabular}{llll}
\hline Kelompok & Mean $(\%)$ & $p$-value & Kesimpulan \\
Pretest & 24,38 & $0,870^{*}$ & $\begin{array}{l}\text { tidak terdapat } \\
\text { perbedaan }\end{array}$ \\
\hline Posttest & 24,16 & &
\end{tabular}

*) Paired t-test 
Diagram 1. Perbandingan Rata-Rata Indeks Plak Ekstrak Kulit Apel Manalagi dan Air Mineral

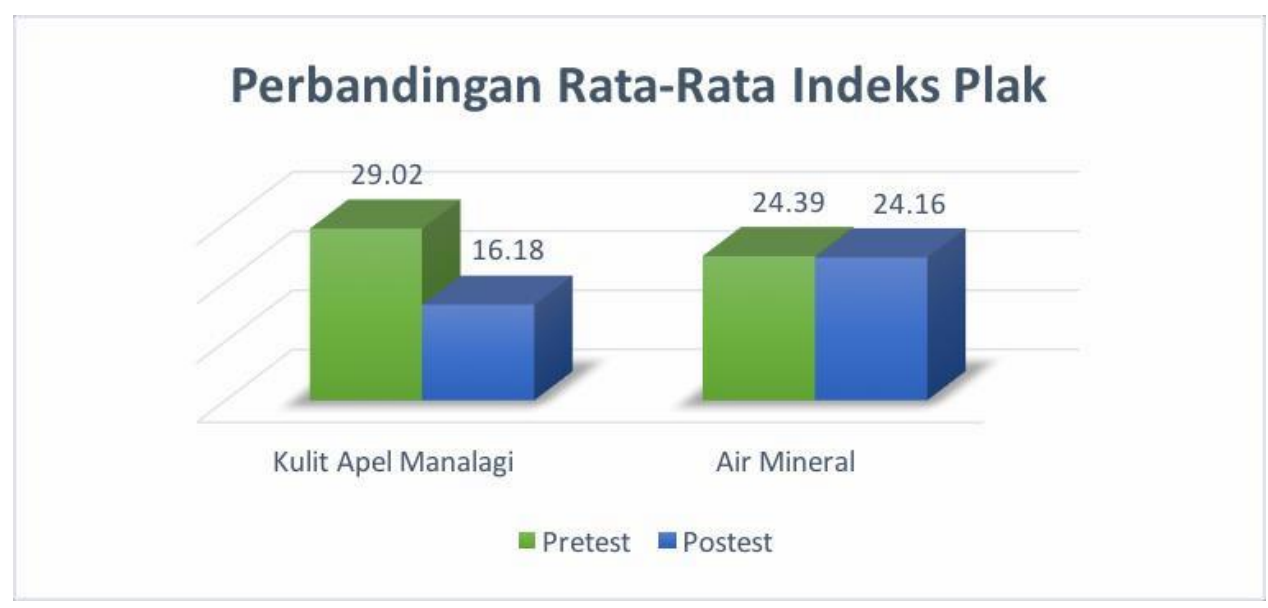

Analisis Persentase Perubahan Indeks Plak Gigi

Persentase perubahan indeks plak yang menggunakan ekstrak kulit apel manalagi (Malus sylvestris Mill.) mengalami penurunan dengan rata-rata penurunan sebesar $44,11 \%$ sedangkan rata-rata persentase penurunan indeks plak yang menggunakan air mineral adalah 1,89\%. Menurut hasil uji t independent dapat dilihat bahwa nilai pvalue < 0,05 maka dapat diartikan bahwa terdapat pengaruh signifikan penurunan indeks plak dengan menggunakan ekstrak kulit apel manalagi (Malus sylvestris Mill.).

Oleh karena itu dapat disimpulkan bahwa ekstrak kulit apel manalagi (Malus sylvestris Mill.) dapat menurunkan indeks plak. Ekstrak kulit apel manalagi (Malus sylvestris Mill.) mampu memberikan perngaruh yang signifikan dalam menurunkan indeks plak dibandingkan dengan air mineral.

Tabel 7. Uji Perbandingan Persentase Perubahan Indeks Plak Gigi

\begin{tabular}{|c|c|c|c|}
\hline Kelompok & Mean & p-value & Kesimpulan \\
\hline $\begin{array}{l}\text { Esktrak Kulit Apel } \\
\text { Manalagi }\end{array}$ & 44,11 & $0,000 *$ & $\begin{array}{l}\text { Terdapat } \\
\text { perbedaan }\end{array}$ \\
\hline Air Mineral & 1,89 & & \\
\hline
\end{tabular}

*)Independent $t$-test

\section{Diskusi}

Plak gigi merupakan deposit lunak yang membentuk lapisan biofilm yang menempel pada permukaan gigi atau permukaan keras lain dalam rongga mulut. Plak gigi merupakan faktor utama dalam proses terjadinya karies gigi dan jaringan 
periodontal.

Pengendalian plak merupakan hal penting dalam mencegah terjadi karies dan penyakit periodontal. Pengendalian plak dapat dilakukan secara mekanik dan kimiawi. Salah satu contoh pengendalian plak secara kimiawi adalah berkumur dengan ekstrak kulit apel manalagi.

Kulit apel manalagi mengandung beberapa senyawa aktif yang dapat mencegah pembentuk plak seperti polifenol, flavonoid, katekin, kuersentin, phloridzin, dan asam klorogenik. Polifenol dapat menghambat glukosiltransferase, enzim yang diproduksi oleh bakteri Streptococcus dan mencegah pembentukan bahan matriks yang digunakan plak untuk melekat pada permukaan gigi. Polifenol bekerja pada enzim alpha amylase untuk menghambat pemecahan karbohidrat, sehingga tidak terjadi pembentukan karbohidrat yang mudah difermentasikan (maltose) oleh bakteri. Bakteri lebih susah hidup karena tidak ada nutrisi sehingga plak yang terbentuk sedikit.

Flavonoid berperan secara langsung sebagai antibiotik dengan mengganggu fungsi dari mikroorganisme seperti bakteri atau virus. Katekin memiliki gugus pyrigallol dan gugus galloil yang dapat menghambat pembentukan plak gigi dengan mencegah pembentukan extracellular glucan yang berfungsi sebagai perlekatan bakteri $S$. mutans pada permukaan gigi.

Kuersetin berperan dengan menngkatkan permeabilitas membran bakteri, sehingga secara signifikan dapat menghambat motilitas dari bakteri. Phloridzin merusak dinding sel bakteri melalui perbedaan kepolaran antara lipid penyusun DNA bakteri dengan gugus alkohol pada senyawa flavonoid, sehingga dinding sel akan rusak dan senyawa tersebut dapat masuk ke dalam inti sel bakteri. Asam klorogenik secara signifikan meningkatkan permeabilitas membran plasma bakteri yang mengakibatkan kebocoran isi sitoplasma termasuk nukleotida.

Penelitian yang telah dilakukan oleh Whita Ovi dengan konsentrasi 25\% membuktikan bahwa kandungan senyawa aktif yang ada pada kulit apel manalagi (Malus sylvestris Mill) memiliki daya antibakteri dan mampu menurunkan indeks plak gigi sehingga dapat mencegah terjadinya penyakit periodontal. Penelitian ini dilakukan kepada dua kelompok, yaitu kelompok yang berkumur dengan esktrak kulit apel manalagi (Malus sylvestris Mill) 12,5\% terjadi penunan rereata indeks plak dari $29,02 \%$ menjadi $16,18 \%$ dengan persentase penurunan sebesar $12,84 \%$ dan pada kelompok yang berkumur dengan air mineral rerata indeks plak dari $24,39 \%$ menjadi $24,16 \%$ dengan persentase penurunan sebesar $0,23 \%$.

Dengan demikian dapat disimpulkan bahwa indeks plak gigi pada kelompok yang berkumur dengan ekstrak kulit apel manalagi (Malus sylvestris Mill) 12,5\% mengalami penurunan yang lebih besar dibandingkan dengan kelompok yang berkumur dengan air mineral. Hal ini menunjukan bahwa ekstrak kulit apel manalagi (Malus sylvestris Mill) 12,5\% lebih efektif dalam menurunkan akumulasi plak dibandingkan dengan air mineral.

\section{Kesimpulan}

Berkumur ekstrak kulit apel manalagi (Malus sylvestris Mill.) 12,5\% dapat menurunkan indeks plak gigi. 


\section{Referensi}

1. Anonim. Riset Kesehatan Dasar RISKESDAS 2013. Jakarta: Kementrian Kesehatan RI. 2013. p: 147.

2. Carramza, F.A., Newman, M.G., \& Takei, H.H. Clinical Periodontology. $9^{\text {th }}$ ed., WB. Saunders, Philadelphia. 2002. p: 97.

3. Reddy Shantipriya. Essentials of Clinical Periodontology and Periodontics, $3^{\text {rd }}$ edition. Jaypee Brothers Co. India. 2011. p: 57-58.

4. Vasanthakumari, R. Textbook of microbiology. New Delhi :BI Publication. 2007. p: 191.

5. Deng, Urch, Cate, Rao, Aalten, Crielaard. Streptococcus Mutans smu.623c Codes for a Functional, Metal - Dependent Polysaccharide Deacetylase that Modulates Interaction with Salivary Agglutinin. J.Bacteriol. Vol (1). 2009. P:394-402.

6. Irianto, Koes. Ilmu Kesehatan Masyarakat. Bandung: Epsilon Grup. 2010. p:83-86

7. Djaenudin Natadisastra. Dasar-Dasar Parasitologi Kedokteran. Dalam: Djaenudin Natadisastra, \& Ridad Agoes, Parasitologi Kedokteran : Ditinjau dari organ tubuh yang diserang. Jakarta: EGC. 2009. p:55.

8. Hanum, N.A., Ismalayani, Syanariah, M. Uji Efek Bahan Kumur Air Rebusan Daun Sirih (Piper betle L.) terhadap Pertumbuhan Plak. J Kes. 2012. Vol. 1 No. 10.

9. Santos, A. Evidence - Based Control of Plaque and Gingivitis. J Clinic Perio. 2003. Vol.30 (S5). p:13-6.

10. Jannata, et al. Daya Antibakteri Ekstrak Kulit Apel Manalagi (Malus sylvestris Mill.) terhadap Pertumbuhan Streptococcus Mutans. J Pus Kes. 2014. Vol. 2(1). p: 6, 23-8.

11. Toedt, John. Koza, Darrell. dan Van Cleef, Kathleen Toedt. Chemical Composition of Everyday Products. Greenwood Publishing Group. USA. 2000. $\mathrm{p}: 48$.

12. Nugroho, I.A. Tanaman Obat Indonesia. Lokakarya nasional tanaman obat indonesia. Balitbang Kehutanan. Bogor. 2010.

13. Wulansari A. Daya Antibakteri Ekstrak Buah apel Manalagi terhadap Bakteri Salmonela Thyposa. J Healthy Sience AAKMAL Vol.2 No.1.2012.

14. Dewi, R.A.P., dan G. Wibisono.Pengaruh Pasta Gigi dengan Kandungan Buah Apel (Pyrus malus) terhadap Pembentukan Plak Gigi. 2011. Available from URL : http://eprints.undip.ac.id/37137/

15. Iswahyudi, C. Perbedaan Model Vinifikasi pada Pembuatan Wine Apel Lokal (Manalagi dan Rome Beuty) terhadap Kemampuan Menangkap Radikal Bebas 1,1-difenil-2- pikrilhidrasil (dpph). In: Seminar Nasional Kedaulatan Pangan Dan Energi, 27 Juni 2012, Fakultas Pertanian, Universitas Trunojoyo Madura. Available from URL: 
http://repository.wima.ac.id/id/eprint/3760

16. Surjowardojo Puguh., Susilorini Tri Eko., Benarivo Vasco. Daya Hambat Dekok Kulit Apel Manalagi (Malus sylvestris Mill.) terhadap Pertumbuhan Escherichia Coli dan Streptococcus Agalactiae Penyebab Mastitis pada Sapi Perah. Jurnal Ternak Tropika Vol.17 No.1. 2016. p:11-21. Available from URL : http://ternaktropika.ub.ac.id/index.php/tropika/article/view/258

17. Kristanti, Hapsari D, Pradono J. Status kesehatan gigi dan mulut di indonesia. Analisis Data Survei Kesehatan Rumah tangga (SKRT) . 2011.

18. Shimizu, K., Igarashi, K., dan Takahashi, N.. Chairside Evaluation of $p H$ Lowering Activity and Lactic Acid Production of Dental Plaque: Correlation with Caries Experience and Incidence in Preschool Children. Quintessence International Vol.30 (2). 2008. p: 151-8.

19. Sabir A. 2010. Aktivitas Antibakteri Non-Flavonoid Propolis Trigona sp terhadap Pertumbuhan Streptococcus Mutans (In Vitro). JITEKGI Vol. 7(1). 2010. p: 37 42.

20. Kidd EAM, Joyston S., Bechal. Dasar - Dasar Karies Penyakit dan Penganggulangnnya. London: EGC. 1992. p:2 - 3.

21. Charde, M. S., Ahmed A., \& Chakole, R. D. Apple Phytochemicals for Human Benefits. Int . J . Pharm . Res . Vol. 1 (2). 2011. p: 1-8.

22. Wijaya, Belina Arum. Perbandingan Efek Atibakteri dari Jus Pir (Pyrus bretschneideri) terhadap Streptococcus Mutans pada Waktu Kontak dan Konsentrasi yang Berbeda. 2008. Undergraduate thesis, Faculty of Medicine. Available from URL: http://eprints.undip.ac.id/24280/

23. Rustanti, E. Jannah, A. Ghanaim Fasya, A. Uji Efektivitas Antibakteri dan Dentifikasi Senyawa Katekin Hasil Isolasi dari Daun Teh (Camellia sinensis L. var. Assamica. Jurnal ALCHEMY Vol.2 No.2. 2009. P:138-49.

24. Chusnie, T. P. T. \& Lamb, A. J. Antimicrobial Activity of Flavonoid. International Journal Antimicroba Agent Vol. 26 (5). 2005. p: 343-56. Available from URL : https://www.ncbi.nlm.nih.gov/pubmed/16323269

25. Gunawan, I.W.A. Potensi Buah Pare (Momordica charantia L) sebagai Antibakteri Salmonella Typhimurium. Makalah disajikan dalam rangka tugas dan melengkapi syarat dalam menempuh Program Pendidikan Sarjana. Universitas Mahasaraswati. 2009.

26. Karunanindhi, A., Thomas, R., Belkum, A., \& Neela, V. In Vitro Antibacterial and Antibiofilm Activities of Chlorogenic Acid Against Clinical Isolates of Stenotrophomonas Maltophilia Including The Trimethoprim/Sulfamethoxazole (TMP/SMX) Resistant Strain. BioMed Research Int Vol. I. 2012. P: 1-24.

27. Carranza, F.A., Newman, M.G., Takel, H.H., dan Klokkevold, P.R. Carranza's Clinical Periodontology 12th Edition. Canada: Elsevier. 2015. p: 144.

28. Fadhlia. Hubungan Rinitis Alergi dan Disfungsi Tuba Eustachius dengan Menggunakan Timpanometri. Fakultas Kedokteran Universitas Sumatera Utara, Medan. 2012.

29. Carranza, F.A., Newman, M.G. Clinical Periodontology, 8th ed. W.B.. Saunders Company. Philadelphia. 1996. p: 493-496

30. Balai Penelitian Tanaman Jeruk dan Buah Subtropika. Sejarah Perkembangan Apel di Indonesia. Badan Penelitian dan Pengebangan Pertanian. Kementrian Pertanian. 2014. Available from URL 
http://balitjestro.litbang.pertanian.go.id/sejarah-perkembangan- apel-di-indonesia/

31. Sunarjono, H. Berkebun 26 Jenis Tanaman Buah. Penebar Swadaya. Jakarta. 2013. p: 156-158.

32. Untung, Onny. Jenis \& Budidaya Apel. Jakarta:Penebar Swadaya. 1994. P: 66,70.

33. Direktorat Jenderal Hortikultura. Statistik Hortikultura Tahun 2005 - 2009. Direktorat Jenderal Hortikultura. Kementerian Pertanian. Jakarta. 2009.

34. Scully C, Petti S. Polyphenols. Oral Health and Disease:a review. J Dentistry. 2009. p:413.

35. Koech, K.R., Wachira, F.N., Ngure, R.M., Orina, I.A., Wanyoko, J.K., Bii, C. and Karori,

S.M. Antifungal Activity of Crude Tea Extracts. African Journal of Agricultural Research Vol. 8. 2013. p: 2086-2089.

36. Subroto MA, Saputro H. Gempur Penyakit dengan Sarang Semut. Jakarta. 2006. p:27-29.

37. Redha A.Flavonoid: Struktur, Sifat Antioksidatif dan Peranannya dalam Sistem Biologis. Jurnal Belian Vol.9. 2010. p: 197.

38. Heneman K, Zidenberg-Cherr S. Some Facts About Flavonols. Nutrition and Health Info- Sheet for Health Professionals Vol. 1. 2008.

39. Sumono A, Wulan A. The Sse of Bay Leaf (Eugenia Polyantha Wight) in Dentistry. Dental Journal Vol.4. 2008. p: 148-149.

40. Limbri SC, Djamhari M, Soebadi B. Daya Antifungi Ekstrak Biji Avokad (Persea americana Mill.) terhadap Pertumbuhan Candida Tropicalis secara In Vitro. Oral Medicine Dental Journal Vol.6. 2014. p:69,71-2.

41. Cushnie, T. P. \& Lamb, A. J. Antimicrobial Activity of Flavonoids. International Journal of Antimicrobial Agents Vol 26. 2005. p: 343-56. Yulianti, Sufrida, Irlansyah, Edi Unaedi \& Mufatis W. Khasiat dan Manfaat Apel. Penerbit AgroMedia: Jakarta Selatan. 2012. p: 25.

42. Ditjen POM. Sediaan Galenik. Departemen Kesehatan Republik Indonesia. Jakarta. 2986. p: $55-60$.

43. Dahlan, Sopiyudin M. Besar Sampel dan Cara Pengambilan Sampel. Jakarta: Salemba Medika. 2013. p: 78-80. 